(Jpn. J. Hosp. Pharm.

(資) $348-357$ (1997)

\title{
酸性電解水（アクア酸化水）および市販消毒薬の 真菌に対する殺菌効果の比較
}

\author{
鎗田響子*，宇野 潤，赤尾三太郎 \\ 千葉大学真核医学研究センター, 高分子活性分野†
}

\section{Comparison of the Fungicidal Action of Acidic Electrolyzed Water (Aqua Oxidizing Water) and Commercial Disinfectants}

\author{
KYOKO YARITA*, JUN UNO and MITSUTARO AKAO \\ Division of Experimental Chemotheraphy, Research Center for Pathogenic \\ Fungi and Microbial Toxicoses, Chiba University $\dagger$ \\ $\left(\begin{array}{l}\text { Received March 10, } 1997 \\ \text { Accepted April 8, } 1997\end{array}\right)$
}

The fungicidal activity of acidic electrolyzed water (Aqua oxidizing water, AQ) and nine commercial disinfectants was studied using three methods of contact on two kinds of pathogenic yeast and two kinds of conidia.

In a glass test tube, with a ratio of I to 9 of Fungal suspension $10^{7} \mathrm{cfu} / \mathrm{ml}$ water to $\mathrm{AQ}$, the fungi were killed by AQ within one minute, but the same amount of AQ was not effective against fungi suspended in a medium of Sabouraud dextrose broth (SDB). The killing activity of $50 \mathrm{ppm}$ sodium hypochlorite (CL), which included the same amount of chlorine as $\mathrm{AQ}$, was weaker than that of $\mathrm{AQ}$ and was also inhibited by SDB. The killing activities of $3 \%$ hydrogen peroxide, $500 \mathrm{ppm} \mathrm{CL}, 1 \%$ chloramine $\mathrm{T}$ (CT) and $0.5 \%$ chlorhexidine gluconate were weaker than that of $\mathrm{AQ}$, but were not inhibited by SDB.

On a stainless steel tray, the fungicidal activity was weaker than the activity observed in the glass tube. After a 30-minute exposure, AQ killed both kinds of yeast completely, but neither type of conidia.

Organic substances influenced the fungicidal activity of $\mathrm{AQ}$. On an agar plate or in the glass tube with proteins, the killing activity of both AQ and $50 \mathrm{ppm} \mathrm{CL}$ was inhibired. The influence of CT, a kind of chloric oxidizer, varied according to the $\mathrm{pH}$ of the substances.

AQ therefore shows a more potent fungicidal activity than ordinary chloric oxidizers with less chlorine because of its acidity, but is inhibited by organic substances to the same extent as CL which includes the same amount of chlorine. In conclusion, AQ is thus considered to be useful in washing and rinsing the surface of materials for the purpose of sterilization.

Key words — disinfectant, electrolyzed water, chloric oxidizer, fungicidal action, sanitizer, inactivation test 
緒言

近年, 抗生物質耐性菌や強毒菌による感染が問 題となり, 消毒の重要性が再認識されてきた1,2). 消毒薬には多くの種類があるが, それぞれ化学薬 品としての長所短所を持つ ${ }^{2,3)}$. アクア酸化水 (AQ) は，三浦電子製のオキシライザーにより, 食塩を添加した水道水を隔膜を介して電気分解す ることによって陽極側に得られる酸化力を持つ強 酸性の水である. 近年, アルカリ水, 強酸性水等 の電解水製造器に多くのメーカーが参入している が, オキシライザーは最も早く開発され，成分， 抗菌力試験, 安全性試験等の研究も進んでい $3^{4-9)}$ ．それらによると $\mathrm{AQ}$ は強い殺菌力を持つ 上, 従来の消毒薬より毒性が低い(10)ため, 病院等 で解頭手術時や, 火傷, 袮瘡の治療, 器具の洗浄 や清掃などに用いられるようになってきてい $3^{4,5,11)}$. 我々は AQの真菌に対する殺菌効果を 種々の接触条件下で 9 種の市販消毒薬と比較検討 した.

\section{材料と方法}

$<$ 材料>

\section{1. アクア酸化水 $(\mathbf{A Q})$}

三浦電子製オキシライザーにより作製し，密閉 して冷暗所保存したものを 1 力月以内に，希釈せ ずに使用した。

\section{2. 市販消毒薬}

局方オキシドール（3\%過酸化水素含有， $\mathrm{OX}$, 吉田製薬)，50ppm および500ppm 次亜塩素 酸ナトリウム $\left(\mathrm{CL}, ヒ^{\prime} ュ\right.$ ラックス, オーヤラッ クス)，1\%クロミラン T (CT, p-トルエンス ルホンクロロアミドナトリウム 3 水和物, 関東化 学), $0.5 \%$ クコン酸クロルヘキシジン $(\mathrm{CH}, 5 \%$ ヒビテン液, ゼネカ製薬), 局方消毒用エタノー ル (76.9〜81.4\%エタノール含有, ET), $5 \%$ 液状フ

$\dagger$ 千葉県千葉市中央区亥鼻 1-8-1 ; 1-8-1, Inohana, Chuuou-ku, Chiba-shi, Chiba, 260 Japan
エノール $(\mathrm{PH}$, 局方液状フェノール $), 2 \%$ ク ゾール石ケン液（CR，局方クレゾール石ケン液） (以上吉田製薬)，0.2および10\%ポビドンョード (PI，イソジン液, 明治製菓)， $2 \%$ イタタールア ルデヒドを使用時炭酸水素ナトリウムで約 $\mathrm{pH} 8$ に調整したもの (GL，グルタールアルデヒド $25 \%$ 水溶液, 半井化学) を使用した。これらは, 微生 物学の教科書等を参考にし，器具の消毒に用いら れる濃度を選んだ ${ }^{12,13)}$ 。

\section{3. 使用菌株と培地}

被検菌として, 酵母は Candida albicans IFM 40009およびCryptococcus neoformans S90145, 系状菌分生子は Aspergillus fumigatus IFM4943お よび Trichophyton mentagrophytes IFM40769を使 用した。菌液調製は「病原真菌・同定法と感受性試 験 $\left.{ }^{14)}\right\rfloor$ 他 ${ }^{15,16)}$ を参考にし, 滅菌精製水またはサブ ローブドゥ糖液体培地（SDB, Sabouraud dextrose broth, Difco）で行った.

被検菌の前培養打よび生菌数測定用寒天平板 (以後，寒天平板)は, 酵母に対しては Sabouraud dextrose agar, 系状菌に対しては potato dextrose agar（共にDifco 社製）を使用した。

\section{<実験方法 $>$}

\section{1. アクア酸化水に対する希釈と菌量の影響}

菌液を滅菌精製水で, $2 \times 10^{4}, 10^{5}, 2 \times 10^{6}$ お よび $10^{7} \mathrm{CFU} / \mathrm{ml}$ に調製した。ふた付きガラス試 験管中で, $10^{5}$ および $10^{7} \mathrm{CFU} / \mathrm{ml}$ の菌液と $\mathrm{AQ}$ を

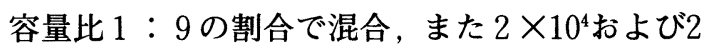
$\times 10^{6} \mathrm{CFU} / \mathrm{ml}$ の菌液と $\mathrm{AQ}$ は容量比 $1 ： 1$ の割合 で混合した，経時的に混合液 $0.1 \mathrm{ml}$ を寒天平板上 に塗布, $27^{\circ} \mathrm{C}$ で静置培養し, 生育コロニー数を測 定し生菌数とした. 生菌数の多い場合は適宜滅菌 精製水で希釈後, 寒天平板に塗布した。

\section{2. 試験管内接触における殺菌効果}

$10^{7} \mathrm{CFU} / \mathrm{ml}$ の菌液を滅菌精製水および SDBを 用いて調製した。ふたた付きガラス試験管中で菌液 と被検液を $1 ： 9$ の割合で混合後, 経時的に混合 液を採取し AQ, 50ppm CL 以外の消毒薬は50倍希 釈した．以下方法 1 と同様 $0.1 \mathrm{ml}$ を寒天平板に塗 
布し生菌数を測定した. 被検液の殺菌効果は, 菌 生存率 $0.05 \%$ 以下になった時の接触時間が 10 秒以 下の時卅, 30秒の時卅, 1 分の時 +10 分の時 ,+ 30 分の時士, 30 分以上の時一として表した.

\section{3. 解放平面上の菌に対する殺菌効果}

$10^{7} \mathrm{CFU} / \mathrm{ml}$ の菌液を滅菌精製水を用いて調製 した.ステンレス製バット $(18 \times 24.5 \mathrm{~cm})$ に置 いた菌液 $1 \mathrm{ml}$ の上へ, $\mathrm{AQ} ま た は ~ E T 10 \mathrm{ml}$ を注ぎ 静かに摇すって混和後, 落下菌による污染を防ぐ ためアルミホイルで軽く覆って30分放置， $3 \times 3$ $\mathrm{cm}$ の滅菌綿 3 個を用いて液を拭き取り，寒天平 板 3 枚に塗布したうえで綿も培養し，生菌数を測 定した。被検液の殺菌効果は, 菌生存率約

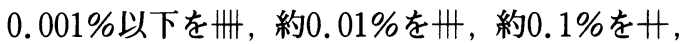
約 $1 \%$ を, 約 $10 \%$, 対照の $50 \%$ 以上生存を

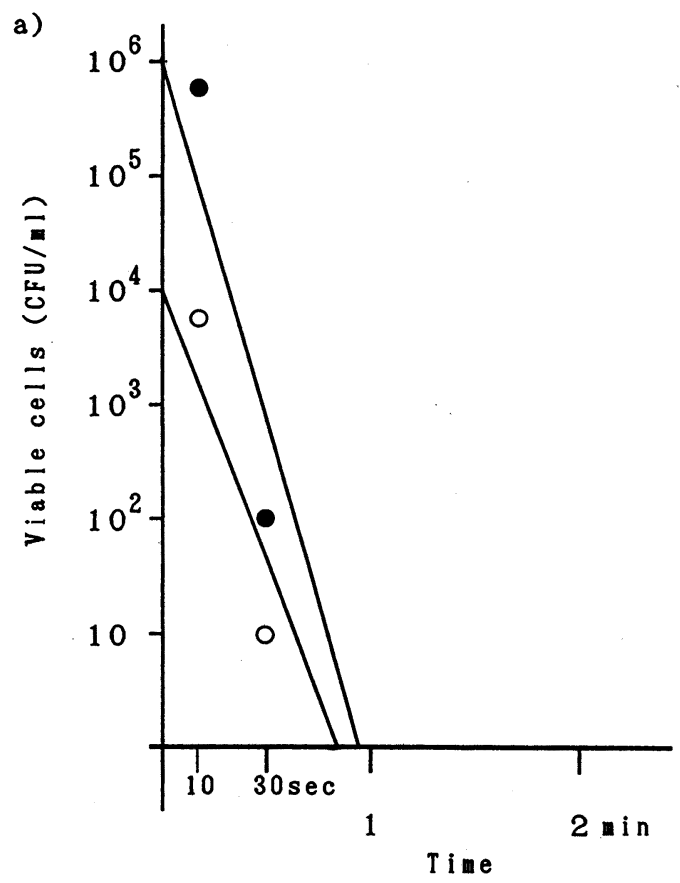

\section{一として表した。}

\section{4. 菌液塗布寒天平板に対する殺菌効果}

$10^{6} \mathrm{CFU} / \mathrm{ml}$ の菌液を滅菌精製水で調製した。 寒天平板上に $0.1 \mathrm{ml}$ の菌液を塗布し，その平板の 中央に被検液を $0.1 \mathrm{ml}$ 適下と同時に直ちに全面塗 布，対照が十分に成育するまで培養して菌の成育 を確認した。すなわち方法 1 とは菌液, 被検液, 培地の接触順序だけが異なる．対照には菌数を 1 / 10ずつに減らしていった平板上に, 滅菌精製水 $0.1 \mathrm{ml}$ を塗布したものを用意した，結果は方法 3 と同様に表した。

\section{5. 試験管内法におけるタンパク質・アミノ酸系 物質の影響}

$\mathrm{AQ}$ と, 塩素系酸化剂 $\mathrm{CL}, \mathrm{CT}$ の殺菌効果に対 するタンパク質・アミノ酸系物質の影響を, 試験

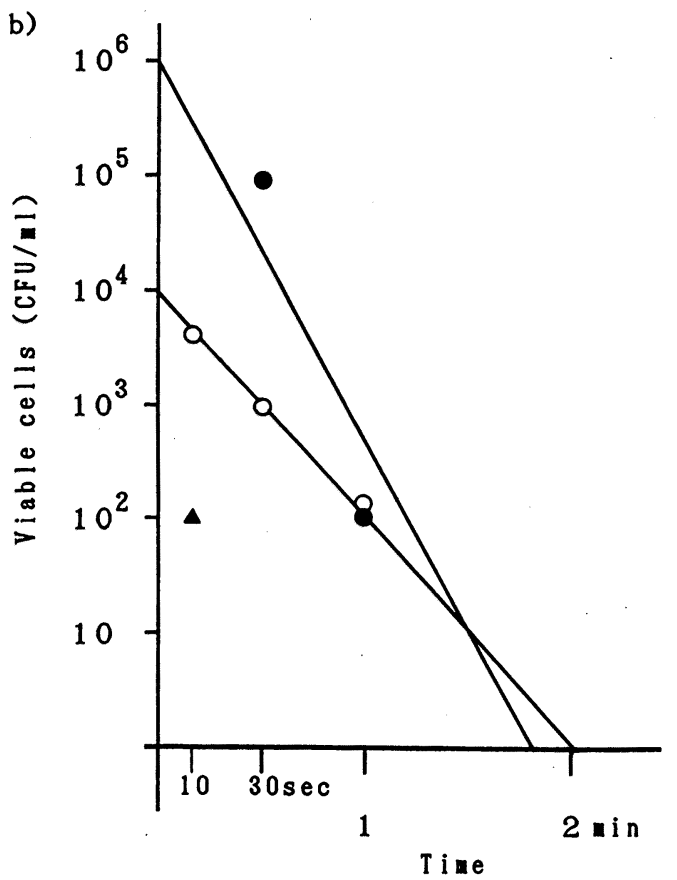

図 1.アクア酸化水の真菌に対する殺菌効果 混合後菌濃度が $10^{6}$ まは $10^{4} \mathrm{CFU} / \mathrm{ml}$ となるよう, 菌液とアクア酸化水を(a) $1 ： 9$ または (b) 1：1の割合で振盪混合後, 経時的に $0.1 \mathrm{ml}$ を寒天板上に塗布し培養, 生菌数を測定した. Asperguillus fumigatus IFM $494310^{6} \mathrm{CFU} / \mathrm{ml}(\bigcirc)$ おび $10^{4} \mathrm{CFU} / \mathrm{ml}(\bigcirc)$, Trichophyton mentagrophytes IFM $4076910^{6} \mathrm{CFU} / \mathrm{ml}(\mathbf{\Delta})$. (a)（b）における Candida albicans, Cryptococcus neo-

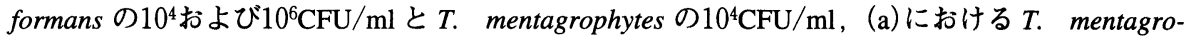
phytes $10^{6} \mathrm{CFU} / \mathrm{ml}$ は，A Qとの接触 10 秒で測定限界以下（10CFU $/ \mathrm{ml}$ 未満）に殺菌されたため 困示されていない. 
管内接触法で調べた. 仔牛血清（千葉県血清研究 所, CS), 仔牛血清アルブミン (半井化学薬品, CSA), ペプトン(ポリペプトン, 日本製薬)，L-

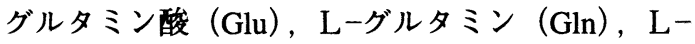
フェニルアラニン $(\mathrm{Phe}), \mathrm{L}$ ースレオニン $(\mathrm{Thr})$, $\mathrm{L}$ ーロイシン (Leu), L-メチオニン (Met) , Lアルギニン (Arg, 以上半井化学薬品および和光 純薬）を表 4,5 中の濃度で含む $10^{7} \mathrm{CFU} / \mathrm{ml}$ 菌 液を用意し, 方法 2 の試験管内接触法で菌生存率 を測定した。

\section{結果}

\section{1. アクア酸化水に対する希釈と菌量の影䇾}

病原真菌 4 種に対し，菌液と $\mathrm{AQ}$ の混合比 1 ： 9 および $1 ： 1$ ，混合後菌濃度 $10^{4}$ およ゙ $10^{6} \mathrm{CFU} /$ $\mathrm{ml}$ を組み合せた 4 通りの条件下で, $\mathrm{AQ}$ の殺菌効 果を調べた結果を図 1 に示す，酵母であるC. albicans, Cr. neoformans はいずれの条件下でも, AQ
との接触10秒で測定限界以下の $10 \mathrm{CFU} / \mathrm{ml}$ 未満に 殺菌されたため, 図中には現れていない，T. mentagrophytes は混合比 1：1，混合後菌濃度 $10^{6}$ $\mathrm{CFU} / \mathrm{ml}$ で接触時間10秒の時のみ生存菌が確認さ れた。最も $\mathrm{AQ}$ に抵抗性を示したA. fumigatus は， $\mathrm{AQ}$ 量が少なくなると殺菌時間が延長され た.すなわち菌液：AQの混合比 $1 ： 9$ と $1 ： 1$ では殺菌時間にほぼ倍の違いがあった。一方，A. fumigatus の菌量と殺菌効果の関係については, 混合後菌濃度 $10^{4} \mathrm{CFU} / \mathrm{ml}$ と $10^{6} \mathrm{CFU} / \mathrm{ml}$ における 殺菌時間に差はなかった。

2. 試験管内接触における殺菌効果

AQ および市販消毒薬の, 菌液: 被検液の混合 比 $1: 9$, 混合後菌濃度 $10^{6} \mathrm{CFU} / \mathrm{ml}$ における殺 菌効果を表 1 に示す. AQ, 50ppm CL 以外の消毒 薬は $0.1 \mathrm{ml}$ で寒天平板上の菌 $100 \mathrm{CFU}$ に対しいく ぶん殺菌効果を現すため, これらの消毒薬に対し ては混合液を50倍希釈後, 寒天平板に塗布した。

表 1. 2 種類の菌調製液による試験管内でのアクア酸化水と消毒薬の殺菌効果

\begin{tabular}{|c|c|c|c|c|c|c|c|c|}
\hline \multirow[b]{2}{*}{ 被検液1) } & \multicolumn{2}{|c|}{ C. albicans } & \multicolumn{2}{|c|}{ Cr. neoformans } & \multicolumn{2}{|c|}{ T. mentagrophytes } & \multicolumn{2}{|c|}{ A. fumigatus } \\
\hline & 水 $^{2)}$ & SDB & 水 & SDB & 水 & SDB & 水 & SDB \\
\hline $\mathrm{AQ}$ & $\left.\mathrm{W}^{33}\right)$ & - & H & - & m & - & \# & - \\
\hline ox & \pm & \pm & + & + & \pm & \pm & + & - \\
\hline 50ppm CL & H & - & H & - & H & - & + & - \\
\hline $500 \mathrm{ppm} \mathrm{CL}$ & Wt & Wm & m & WH & W & H & H & + \\
\hline CT & m & H & m & W & \pm & m & \pm & + \\
\hline $\mathrm{CH}$ & m & H & mI & mI & \pm & - & - & + \\
\hline ET & mI & 冊 & HI & HI & m & WI & m & WI \\
\hline PH & 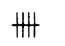 & \# & W & 世\# & 冊 & 世曲 & 冊 & 冊 \\
\hline $\mathrm{CR}$ & 曲 & \# & m & m & WI & WI & WI & HW \\
\hline $0.2 \% \mathrm{PI}$ & m & W & \#I & m & 冊 & 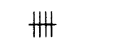 & 曲 & 世 \\
\hline GL & W & \# & HI & WI & m & m & mI & HW \\
\hline
\end{tabular}

試験管に被検液を $0.9 \mathrm{ml}$ 取り, $10^{7} \mathrm{CFU} / \mathrm{ml}$ の菌液を $0.1 \mathrm{ml}$ 加え，振湯混合後，経時的に $0.1 \mathrm{ml}$ を寒天平板上 に塗布し培養, 生菌数を測定した。

1) $\mathrm{AQ}$ : アクア酸化水, $\mathrm{OX}$ : オキシドール, $\mathrm{CL}$ ：次亜塩素酸ナトリゥム, $\mathrm{CT}: 1 \%$ ロラミン $\mathrm{T}$

$\mathrm{CH}: 0.5 \%$ ルコン酸クロルヘキシジン, ET：消毒用エタノール, PH： $5 \%$ 液状フェノール,

$\mathrm{CR}: 2 \%$ クレゾール石ケン液, PI : ポビドンヨード, GL：2\%グルタールアルデヒド炭酸水素ナトリ ウム溶液。

2 ）菌調製に使用した液体.SDB：サブローブドウ糖液体培地.

3 ）殺菌効果. 卅：菌生存率 $0.05 \%$ 以下になる時間が 10 秒以下, $\# ： 30$ 秒, + ： 1 分, $+: 10$ 分, $\pm:$ 30分, - : 30分以上. 
$\mathrm{AQ}$ の精製水中の殺菌効果は, C. albicans, Cr. neoformans, T. mentagrophytes に対しては10秒間 の接触により，A. fumigatus は30秒間の接触によ り測定限界以下の $10 \mathrm{CFU} / \mathrm{ml}$ 未満にする強力なも のであった。しかし SDB 存在下では著しく殺菌 効果を失い，30分接触でも菌はほとんど生存して いた。

一般の器具消毒に用いられる塩素量 $50 \mathrm{ppm} \mathrm{CL}$ の殺菌効果は，精製水中では $\mathrm{AQ} よ り$ 殺菌時間が 長く, SDB 存在下では AQ と同様に阻害され, 30 分後でも菌はほとんど生存していた，污物の消毒 に用いられる塩素量 $500 \mathrm{ppm}$ CL の精製水中での 殺菌効果は, AQ と比較すると, 酵母に対しては

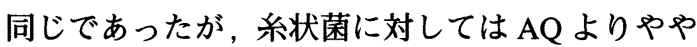
劣っていた。しかし SDB 存在下での殺菌効果 は, AQ P50ppm CL ほど阻害を受けなかった。

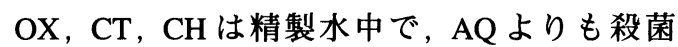
に時間がかかったが, SDB 存在下でもほとんど 影響をうけず，CT はかえって SDB 存在下の方が 殺菌力が高まる傾向があった。 $\mathrm{CH}$ は酵母に対し ては強力であったが，分生子に対しては精製水調 製菌でも30分で A. fumigatus が約 $10^{3} \mathrm{CFU} / \mathrm{ml}$ 生存 していた。これらの結果より，C. albicans, $C r$.

表 2，バット上におけるアクア酸化水と消毒用 エタノールの殺菌効果

\begin{tabular}{|c|c|c|}
\hline \multirow[b]{2}{*}{ 被検菌 } & \multicolumn{2}{|c|}{ 被検液1) } \\
\hline & A Q & $\mathrm{ET}$ \\
\hline C. albicans & $\mathrm{m}^{2)}$ & m \\
\hline $\mathrm{Cr}$. neoformans & HWI & m \\
\hline T. mentagrophytes & H & \# \\
\hline A. fumigatus & H & \#* \\
\hline
\end{tabular}

$18 \times 24.5 \mathrm{~cm}$ のステンレスバット上に $10^{7} \mathrm{CFU} / \mathrm{ml}$ の菌 液を $1 \mathrm{ml}$ を置き, 被検液 $1 \mathrm{ml}$ を上に注ぎ, 静かに摇 すって混和後30分放置. 滅菌綿で全面に完全に拭き取 り, 寒天平板 3 枚に塗布した上, 綿も乗せて培養し, 生菌数を測定した。

1) AQ: アクア酸化水, ET : 消毒用エタノール.

2) 殺菌効果. 冊 : 菌生存率約 $0.001 \%$ 以下 (*以外 は菌検出されず) $, \mathrm{H}:$ 約 $0.01 \%, H ：$ 約 $0.1 \%$. neoformans, T. mentagrophytes, A. fumigatus の順 に消毒薬に対する抵抗性が弱いことが示された。

ET， PH， CR，0.2\%PI，GLは，精製水調製 でもSDB 調製でも変わりなく, どの菌に対して も短時間で強力な殺菌作用を示した。

\section{3. 解放平面上の菌に対する殺菌効果}

$\mathrm{AQ}$ およびETのバット上での接触30分後にお ける効果を表 2 に示す. AQ との接触30分によ り，酵母は 2 種共検出できなくなったが，分生子 は T. mentagrophytes が $3 \times 10^{2} \mathrm{CFU} / \mathrm{ml}$. A. fumigatus は $10^{3} \mathrm{CFU} / \mathrm{ml}$ が検出された. ET は, 酵母 2 種と T. mentagrophytes を検出できなくしたが, A. fumigatusは $2 \times 10 \mathrm{CFU} / \mathrm{ml}$ が検出された(表 2 $*$ ).

表 3 ，寒天平板上におけるアクア酸化水と消毒 薬の殺菌効果

\begin{tabular}{|c|c|c|}
\hline \multirow[b]{2}{*}{ 被検液1) } & \multicolumn{2}{|c|}{ 被検菌 } \\
\hline & C. albicans & A. fumigatus \\
\hline $\mathrm{AQ}$ & $-2)$ & - \\
\hline ox & W & m \\
\hline 50ppm CL & - & - \\
\hline $500 \mathrm{ppm} \mathrm{CL}$ & - & - \\
\hline CT & - & - \\
\hline $\mathrm{CH}$ & H & - \\
\hline ET & \pm & - \\
\hline $\mathrm{PH}$ & + & $+^{*}$ \\
\hline CR & H & + \\
\hline $0.2 \% \mathrm{PI}$ & + & \pm \\
\hline $10 \%$ PI & 冊 & 册 \\
\hline GL & $+^{*}$ & $t^{*}$ \\
\hline
\end{tabular}

寒天平板上に $10^{6} \mathrm{CFU} / \mathrm{ml}$ の菌液 $0.1 \mathrm{ml}$ を塗布後, さらに被検液 $0.1 \mathrm{ml}$ を塗布し対照が十分生育する まで培養，菌の生育を確認した。

1) $\mathrm{AQ}$ :アクア酸化水, $\mathrm{OX}$ : オキシドール, $\mathrm{CL}$ : 次亜塩素酸ナトリウム, $\mathrm{CT} ： 1 \%$ ク ラミン $\mathrm{T}, \mathrm{CH}: 0.5 \%$ グルコン酸クロルへキ シジン，ET：消毒用エタノール，PH：5\% 液状フェノール, CR：2\%クレゾール石ケ ン液, PI：ポビドンョード, GL：2\%グル タールアルデヒド炭酸水素ナトリウム溶液.

2 ) 殺菌効果. $\mathrm{m}$ : 菌生存率約 $0.001 \%$ 以, $\mathrm{W}$ : 約 $0.01 \%,+$ : 約 $0.1 \%,+:$ 約 $1 \%, \pm:$ 約 $10 \%,-: 50 \%$ 以上, ${ }^{*}:$ 平板の周縁部にコ ロニーが現れたもの. 


\section{4. 菌液塗布寒天平板に対する殺菌効果}

$\mathrm{AQ}$ と市販消毒薬が，すでに培地上にある菌に 対しどの程度効力を持つかを検討したところ，表 3 の結果が得られた. AQ と $50 \mathrm{ppm}$ および500ppm CL を塗布した菌平板は，対照と菌成育が変わら なかった. ET と CT も対照に近い菌成育を示し た。一方 OX と $10 \%$ PI は菌成育を完全に抑制し た．他の消毒薬は菌成育を完全には抑制しなかっ た. 10 種の被検液の効果を酵母と糸状菌で比較す ると, 同じか若干系状菌に対し抑制効果が弱かっ たが， CH は著しく系状菌の抑制効果が弱かっ た. $\mathrm{PH}$ は A. fumigatus に対し滴下位置より離れ るにつれコロニーが出現した，GLは，C. albicans, A. fumigatus 両方で上記の傾向が見られ

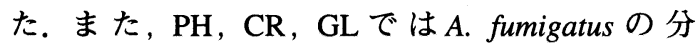

生子がほとんどできず，白いコロニーであった．

5. 試験管内法に対するタンパク質・アミノ酸系 物質の影響

$\mathrm{AQ}$ と CL, CT の殺菌作用に対する CS, CSA， SDB の成分であるぺプトンの影響を試験管内接 触で調べた結果を表 4 に，酸性アミノ酸 Glu, Glu のアミド Gln,芳香族アミノ酸 Phe,水酸基を含む アミノ酸 $\mathrm{Thr}$,炭化水素系アミノ酸 Leu,含硫アミ ノ酸 Met, 塩基性アミノ酸 Argの影響を調べた結 果を表 5 に示す，CL，CT に対するアミノ酸の影 響は，中間の消毒薬抵抗性を示した $T$. mentagrophytes についてのみ調べた.

$\mathrm{CS}$ は $\mathrm{AQ}, \mathrm{CL}$ の殺菌効果に対し阻害傾向を示 した.この阻害は濃度依存的であり，実験 2 の結 果におけるSDB 存在下の場合と同じく，酵母に

表 4.アクア酸化水と次亜塩素酸ナトリウム, クロラミン $\mathrm{T}$ に対するタンパク質系物質の影響

\begin{tabular}{|c|c|c|c|c|c|c|c|c|c|}
\hline \multirow{2}{*}{ 被検菌 } & \multirow{2}{*}{\multicolumn{2}{|c|}{ 被検液1) }} & \multirow{2}{*}{ なし } & \multicolumn{2}{|c|}{ 仔牛血清 } & \multicolumn{2}{|c|}{ 仔牛血清アルブミン } & \multicolumn{2}{|c|}{ ペプトン } \\
\hline & & & & $1 \%$ & $0.1 \%$ & $0.1 \%$ & $0.01 \%$ & $1 \%$ & $0.1 \%$ \\
\hline \multirow[t]{4}{*}{ C. albicans } & & $\mathrm{AQ}$ & $\mathrm{W}^{22}$ & WI & 冊 & H & HW & - & WI \\
\hline & $50 \mathrm{ppm}$ & $\mathrm{CL}$ & H & H & W & ND & ND & - & + \\
\hline & $500 \mathrm{ppm}$ & $\mathrm{CL}$ & HI & WI & WI & ND & ND & H & mI \\
\hline & & $\mathrm{CT}$ & H & H & 世 & H & H & + & W \\
\hline \multirow[t]{4}{*}{ Cr. neoformans } & & $\mathrm{AQ}$ & HI & \# & WI & + & WI & - & W \\
\hline & $50 \mathrm{ppm}$ & $\mathrm{CL}$ & H & H & W & ND & ND & - & + \\
\hline & $500 \mathrm{ppm}$ & $\mathrm{CL}$ & HI & 冊 & HI & ND & ND & W & 册 \\
\hline & & $\mathrm{CT}$ & H & H & H & + & H & + & H \\
\hline \multirow[t]{4}{*}{ T. mentagrophytes } & & $\mathrm{AQ}$ & HW & H & 世冊 & \pm & m & - & + \\
\hline & $50 \mathrm{ppm}$ & $\mathrm{CL}$ & H & + & H & ND & ND & - & + \\
\hline & $500 \mathrm{ppm}$ & $\mathrm{CL}$ & H & 卅 & H & ND & ND & + & H \\
\hline & & $\mathrm{CT}$ & \pm & \pm & \pm & - & \pm & + & + \\
\hline \multirow[t]{4}{*}{ A. fumigatus } & & $\mathrm{AQ}$ & \# & - & H & - & H & - & - \\
\hline & $50 \mathrm{ppm}$ & $\mathrm{CL}$ & + & 一 & + & ND & ND & - & - \\
\hline & $500 \mathrm{ppm}$ & $\mathrm{CL}$ & H & H & H & ND & ND & + & H \\
\hline & & $\mathrm{CT}$ & \pm & \pm & \pm & - & \pm & + & + \\
\hline
\end{tabular}

試験管に被検液を $0.9 \mathrm{ml}$ 取り, 表中の濃度のタンパク質系物質を含む $10^{7} \mathrm{CFU} / \mathrm{ml}$ の菌液を $0.1 \mathrm{ml}$ 加 え振盪混合後, 経時的に $0.1 \mathrm{ml}$ を寒天平板上に塗布し培養, 生菌数を測定した.

1) $\mathrm{AQ}:$ アクア酸化水, CL：次亜塩素酸ナトリウム, CT : $1 \%$ クロラミン T

2 ) 殺菌効果. 卅：菌生存率 $0.05 \%$ 以下になる時間が 10 秒以下, $\#: 30$ 秒, + ： 1 分, + : 10分, 土：30分, 一: 30分以上. ND : 試験せず. 
表 5 。アクア酸化水と次亜塩素酸ナトリウム, クロラミン $\mathrm{T}$ に対するアミノ酸の影響

\begin{tabular}{|c|c|c|c|c|c|c|c|c|c|}
\hline 被検菌 & 被検液1) & なし & $\begin{array}{r}\mathrm{Glu}^{2)} \\
1 \%\end{array}$ & $\begin{array}{l}\text { Gln } \\
1 \%\end{array}$ & $\begin{array}{l}\text { Phe } \\
1 \%\end{array}$ & $\begin{array}{l}\text { Thr } \\
1 \%\end{array}$ & $\begin{array}{l}\text { Leu } \\
1 \%\end{array}$ & $\begin{array}{l}\text { Met } \\
1 \%\end{array}$ & $\begin{array}{l}\mathrm{Arg} \\
1 \%\end{array}$ \\
\hline C. albicans & $\mathrm{AQ}$ & $\left.\mathrm{m}^{3}\right)$ & + & \pm & \pm & \pm & - & - & - \\
\hline Cr. neoformans & $\mathrm{AQ}$ & WH & \pm & \pm & \pm & - & - & - & - \\
\hline \multirow[t]{3}{*}{ T. mentagrophytes } & $\mathrm{AQ}$ & 世 & \pm & - & \pm & \pm & \pm & - & - \\
\hline & 50ppm CL & $H$ & \pm & - & + & \pm & - & - & - \\
\hline & CT & \pm & H & $H$ & + & + & + & + & \pm \\
\hline A. fumigatus & $\mathrm{AQ}$ & H & - & - & - & - & - & - & - \\
\hline
\end{tabular}

試験管に被検液を $0.9 \mathrm{ml}$ 取り, $1 \%$ のアミノ酸を含む $10^{7} \mathrm{CFU} / \mathrm{ml}$ の菌液を $0.1 \mathrm{ml}$ 加え, 振盪混合後,

経時的に $0.1 \mathrm{ml}$ を寒天平板上に塗布し培養, 生菌数を測定した.

1) $\mathrm{AQ}$ : アクア酸化水, $\mathrm{CL}$ : 次亜塩素酸ナトリウム, $\mathrm{CT}: 1 \%$ クロラミン $\mathrm{T}$

2) Glu : L-グルタミン酸, Gln : L-グルタミン, Phe : L-フェニルアラニン, Thr：L-スレオニ

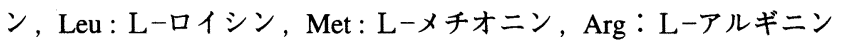

3 ) 殺菌効果. 卅：菌生存率 $0.05 \%$ 以下になる時間が 10 秒以下, $\#: 30$ 秒, + ： 1 分, + : 10分, $\pm: 30$ 分, - : 30分以上.

対しては阻害の影響は弱く，糸状菌に対しては強 く現れた。そして SDB 存在下と同じく，CL は塩 素量の多い方が阻害を受けにくかった。ここで使 用した濃度の CS は，500ppm CL と CT の殺菌効 果に対して影響しなかった。

CSA は AQ, CT の殺菌効果に対し濃度依存的 に阻害傾向を示したが, 阻害の強さはCSよりず っと強かった.

ペプトンは AQ と CL の殺菌効果をやはり濃度 依存的に阻害し, CL は塩素量の多い方が阻害を 受けにくかった. CTに対してぺプトンは，酵母 に対する殺菌効果を濃度依存的に阻害したが, 分 生子に対する殺菌効果は増強した。これらの結果 は実験 2 の SDB 存在下における AQ, CL, CT の 殺菌効果と似た傾向である.

アミノ酸は $\mathrm{AQ}$ の殺菌効果を阻害したが，特に 含硫アミノ酸 Met と塩基性アミノ酸 Arg の阻害 が強く，30分でも菌はほとんど生存していた。一 方, 酸性アミノ酸 Glu は阻害が弱かった。その他 のアミノ酸は中間の強さの阻害を示した，CLに 対しては50ppm, T. mentagrophytes のみの試験で あるが，どのアミノ酸も50ppm CL の殺菌作用を 阻害した. Met, Arg 存在下では30分でも菌はほ とんど生存していたが, AQの場合と異なり Glu が特にCLに対し阻害が弱い結果は出なかった. CT に対しても T. mentagrophytes のみの試験であ るが, Arg 以外のアミノ酸はかえって CT の殺菌 時間を短縮し, その作用は Glu が最も強く, 次に Glnであった。

\section{考察}

$\mathrm{AQ}$ の殺菌効果の本体は酸化作用と考えられ，

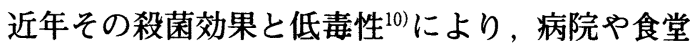
で患部や器具の殺菌洗浄・清掃に用いられてい る $^{4,5,11)}$. 無色透明で塩素臭があり，口にすると 酸味を感じ， ヨードカリでんぷん紙を紫色に変色 させる. $\mathrm{pH}$ 約 2.6 , 酸化還元電位約 $1100 \mathrm{mV}$, 塩 素約25〜 50ppm を主に塩素ガスの状態で含んで おり ${ }^{4,5)}$, これらの成分值は製造時の調整が可能 である. 我々は主要な病原真菌を用いて, その殺 真菌効果を種々の市販消毒薬と比較検討した。

消毒薬には様々な種類があり, 界面活性剤, ビ 
グアナイド系, 酸素系酸化浏, アルコール系, フ エノール系, ハロゲン系 (塩素系, ヨウ素系), ア ルキル化㓮, 重金属, 色素, 酸, アルカリ等に分 類される ${ }^{2,12)}$ が, $\mathrm{AQ} は$ 塩素系, しかし CL, CT を含む一般の塩素系酸化浏とは異なり酸性である 塩素系酸化烱ということがいえるであろう。

今回行った様々な接触方法から, 酵母は系状菌 より消毒薬に対する抵抗性が弱いことが示され た。また我々は，大分生子，菌系が A. fumigatus 等の糸状菌分生子より抵抗性を示した結果を得て いる ${ }^{17)}$.

$\mathrm{AQ}$ は, 最も単純な系であるガラス試験管中で 精製水調製菌と接触させる方法では, OX, CL, $\mathrm{CT}, \mathrm{CH}$ より強い殺菌作用を示し，その強さは500 ppm CL と同程度であった. CT は $1 \%$ 約 3700 $\mathrm{ppm}$ の塩素を含む有機化合物であり，塩素の遊 離が徐々に行われるため，作用は緩やかだが持続 性があるとされ，事実結果からも CT は殺菌時間 の長いことが示された。しかし AQは SDB 調製 の菌液では効果が失われたが，市販消毒薬は $\mathrm{AQ}$ とほぼ同じ塩素量である50ppm CL を除き，ほと んど阻害を受けなかった。れらのことから $\mathrm{AQ}$ は夾雑物に影響されやすいことが示唆されたが, これは含有塩素量に基づくものと思われた。

次にやや実際の条件に近づけて, AQ と ETの 効果をステンレスバット上で比較したところ, 試 験管内よりも大きく効果が落ちることが示され た. 精製水調製菌を用い, 接触30分後に生存菌を 確認したところ, $\mathrm{AQ}$ の場合は，酵母 2 種はいず れも検出できなかったが, 分生子は 2 種いずれも 生存していた. ETの場合も，A. fumigatus がわ ずかに生存していた。これは，解放系では塩素ガ スやET が蒸散しやすいことと, 試験管内接触で は初めに振盪混合するためと考えられる．故にこ れらの薬剤による実際の消毒作業を実施する場 合，一度だけではなく何度か繰り返すことが必要 と考えられた。

次に寒天培地に塗布した菌に対する殺菌作用を みると， AQ と，CL の50ppm，500ppm が共に全
く対照と同じ発育を示した。他に CT と, 試験管 内では強力であった ET がほとんど無効であっ た. OX を除き他の消毒薬の殺菌効果も落ちた. 寒天培地はSDB 調製菌液よりも, 有機物が圧倒 的に多量であり，この実験から塩素系酸化剛に次 いで，ET が有機物により不活化されやすいこと が示された. 塩素系酸化浏と同じハロゲン系消毒 薬のPIも同じくタンパク質により阻害される が，ヨード系は塩素系より安定とされている。す なわち, より不安定な塩素系酸化剛が, よりタン パク質に作用し消費されたため，影響を大きく受 けたことが示された. ET の作用の減弱は, 蛋白 凝固や有機物への吸着などによる消費によると思 われた。

OX のみが, 寒天培地の方が, 試験管内接触よ りも強力な殺菌効果を現した. OX は有機物と接 触することにより, 活性酸素を放出し殺菌作用を 示すことから, かえって寒天培地上の方が効力が 強く現れたと思われる。 また PH， GLでは滴下 した部位から離れるにつれコロニーが出現した が，これは薬剤の浸透性が良すぎたためであり， 石畧の含まれている CR は, PHより液が寒天表 面に広がりやすくそのためコロニーが均等に出現 したと考えられた. PH， CR， GLではA. fumigatus の分生子がほとんどできず白いコロニーであ ったが，これらには分生子生成抑制作用があると 考えられた。

未発表であるが，2000CFUの酵母または分生 子を混釈した $15 \mathrm{ml}$ 相当の寒天平板に $\mathrm{AQ}$ を重層

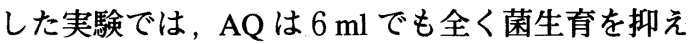
なかったうえ, 糸状菌のコロニー発現後に投与し た場合は，菌体の撥水性のためコロニーの部分は 穴があき，菌には接触していないようであった。

$\mathrm{AQ}$ は有機物で阻害される を菌液に共存させて, CL, CT と比較した. CS と CSA による阻害実験の結果をみると, CSAの 阻害効果は同濃度の CS に比し, ずっと強く 10 倍 以上である. CS による阻害をタンパク質のため と想定すると, 血清中のタンパク質含量は数\%と 
なるが，実際に血清中のタンパク質は動物種によ って多少の差があるがいずれも一桁台である.

$\mathrm{SDB}$ の組成は $1 \%$ のペプトンと $2 \%$ の゙ドゥウ 糖であり，未発表であるが50\%ブドウ糖と寒天培 地中の濃度である1.5\%のゲル状にした寒天は， $\mathrm{AQ}$ の殺菌効果に影響しなかったので，SDBによ る阻害もタンパク質であるぺプトンによると考え られる.SDBと $1 \%$ ケプトンの結果を比較する と, CTにおいて, 消毒薬抵抗性の高い菌にかえ って殺菌時間の短縮がみられ，その効果はSDB の方が強かった，CL，CT を含む一般の塩素系酸 化肪は塩基性であり, 徐々に活性塩素を放出す る.塩基性下では次亜塩素酸イオンになるが, 酸 性下では揮発性の塩素ガスとなり殺菌力が強まる

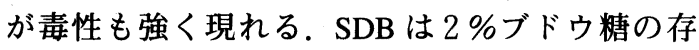
在により，1\%ペプトンより酸性であるので, こ の殺菌力の違いは液性によるものと推測された.

そこで, 各グループのアミノ酸から代表的なも の 1 種ずつを選び, 塩素系酸化㓮の殺菌効果に対 する影響を調べた結果， AQ，50ppm CL に対して は，いずれのアミノ酸も殺菌作用を阻害したが， そのうち含硫アミノ酸 Met と塩基性アミノ酸 Arg は阻害が最も強く，ほぼ完全に殺菌作用を抑制し た. 酸性アミノ酸 Glu は, AQ に対しては 4 菌種 とも, アミノ酸中もっとも阻害が弱く, 残りのア ミノ酸は塩基性アミノ酸と酸性アミノ酸の中間の 強さで AQを阻害した。しかし50ppm CLに対し ては，T. mentagrophytesのみの結果だが, Glu がもっとも阻害が弱い結果は出なかった. CT は 塩基性アミノ酸 $\mathrm{Arg}$ を除いて, かえって殺菌力 が増強され，ことに酸性アミノ酸による増強が著 しく, 次いで Glu の酸アミド Gluであった.

これらの結果から塩素剤の含有塩素量の多いほ ど, 酸性化による塩素遊離量が大きく, 殺菌力が 増したと考えられたので, pH 試験紙とヨードカ リでんぷん紙, 酸化還元電位計を用い, 各アミノ 酸と $\mathrm{AQ}, \mathrm{CL}, \mathrm{CT}$ との反応前後の液性と酸化力 を調べた. AQ は強酸性で, ヨードカリでんぷん 紙を瞬間的に濃い紫色に変え, 酸化還元電位は
$1160 \mathrm{mV}$ 前後である. AQ は, Met 添加により瞬 間的にヨードカリでんぷん紙を紫変しなくなった が, 液性は強酸性のままであった. Arg 添加によ っては，30後にもヨードカリでんぷん紙を紫変す るにもかかわらず強塩基性になった。この時, 酸 化還元電位は30分で430mVに下がった．他のア ミノ酸添加によっては, 強酸性のままであるにも かかわらず, ヨードカリでんぷん紙はほとんど紫 変しなくなった.

50ppm CL は, 塩基性でヨードカリでんぷん紙 を紫色に変え, 酸化還元電位は約 $800 \mathrm{mV}$ であ

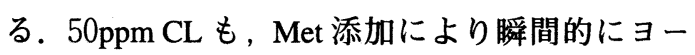
ドカリでんぷん紙を紫変しなくなったが, 液性は アミノ酸の液性である酸性のままであった. Arg 添加によってはヨードカリでんぷん紙はほとんど 紫変しなくなり, 強塩基性になった.この時, 酸 化還元電位は30分で380mVに下がった．他のア ミノ酸添加によっては, アミノ酸の液性である酸 性からほとんど変わらず, ヨードカリでんぷん紙 の紫変力も 30 分後でもほとんど減弱しなかった.

CT は, 塩基性でョードカリでんぷん紙を瞬間 的に濃く紫変するが，10秒ほどで白く脱色され る.アミノ酸添加によってヨードカリでんぷん紙 の変色は影響を受けなかったが, 液性に対しては アミノ酸によって違いがあり, Arg 添加では強塩 基性のままで, Glu 添加では酸性, 他は中性にな った.

これらのことから, $\mathrm{AQ}$ と50ppm CL はアミノ 酸により阻害されるが, さらに Met のような還 元作用のある物質によっては塩素が著しく消費さ れて強い阻害を受け, また $\mathrm{pH}$ の上昇によって遊 離塩素が次亜塩素酸イオン型に移行することによ り, 殺菌作用が阻害されると考えられた。また CT は塩素量が多いため $1 \%$ \%ノ酸および Met によっても塩素が完全に消費されず, 酸性化によ りかえって殺菌力が増強したと考えられた。

未発表であるが, 他の有機物では界面活性浏も 阻害を起こし, 特に非イオン性のツイン80の阻害 が強く, 陰イオン性界面活性剤の阻害は弱かっ 
た. 考察でも一部言及した炭水化物類はほとんど 影響しなかった。また。これまでにあげた有機物 は，配合禁忌が多いとされる $\mathrm{CH}$ ，寒天平板で大 きく阻害された ET に対しては阻害を起こさなか った。

結論として $\mathrm{AQ}$ は，500ppm CL に勝る殺真菌力 を持ち,タンパク質・アミノ酸系物質による阻害 の受けやすさは同じ塩素量の CL とほぼ同程度で あることがわかった．他の消毒薬にも試験管内の 滅菌精製水中での接触試験と有機物存在下での接 触試験で, 効力に差が見られたものが多く, CH は分生子に対して効力が劣った. AQに限らず消 毒薬が実際に使用される場合は有機物の共存下と 考えられるため, 実際の使用にあたってはこれら の点に注意すべきであろう。しかし $\mathrm{AQ}$ は，酸性 であるため10倍の塩素量を含む CL より速効性で あり，水道水から用時製造されるため, CL の希 釈調製より簡便で安全である，CL はその低残留 性から, 食品・食器に推奨される消毒薬であり, 低濃度では洗浄用としてすすがずに乾燥させて使 用される ${ }^{18,19)}$ が， AQ の塩素は，酸性下塩素ガス の状態で含まれているため，さらに低残留性であ る． $\mathrm{AQ}$ を洗浄・すすぎに使用することは，特に 医療・食品関係の分野では有用と思われた.

\section{引用文献}

1) 朝長文弥他, 病院薬学, 11, 122-127 (1985).

2) 防菌防徽剂事典出版委員会編, “防菌防徽剤事 典”, 日本防菌防徽学会, 大阪, 1986 .

3) 丸石製薬株式会社学術部, “院内感染防止のた めの消毒剤使用法の基本”, 丸石製薬株式会社, 大阪, 1995.

4）アクア酸化水研究会, “アクア酸化水使用手引”,
岡田淳編, 日本特殊分析研究所, 東京, 1995 .

5）芝紀代子, 芝燁彦, “強電解水ハンドブック”, 医学情報社, 東京, 1995.

6) 岩沢篤郎, 中村良子, 水野徳次, 環境感染, 8, 11 -16 (1993).

7) 岩沢篤郎, 中村良子, 中村國衛, 村井哲也, 薬 理と臨床，3，1555-1562 (1993).

8) 岩沢篤郎, 中村良子, 臨床と微生物, 20, 469-472 (1993).

9) 岩沢篤郎, 中村良子, 岡田淳, 水野徳次, 臨床 と微生物, 20, 231-236 (1993).

10) 岩沢篤郎, 中村良子, 日本環境感染学会誌, 9, 12 -18 (1994).

11）宮崎宗，鬼頭健一，森信彦，脳神経外科速報， 3, 779-782 (1993).

12）久恒和仁, “戸田新細菌学”,森良一; 天児和暢 編, 南山堂, 東京, 1993, pp.119-131.

13）川名林治, “シンプル微生物学”, 東匡伸, 小熊 恵二編, 南江堂, 東京, 1990, pp.57-61.

14）宇野潤，“病原真菌一同定法と感受性試験一”, 宮治誠，西村和子，宇野潤編，廣川書店，東京， 1992, pp.205-228.

15) National Committee for Clinical Laboratory Standards, "Reference method for broth dilution antifungal susceptibility testing of yeast ; proposed standard", 15, no.10, National Committe for Clinical Laboratory Standards, 1997.

16）山口英世, 内田勝久他, 日本医真菌学会標準化 委員会報告(1992 1994 年), 日本医真菌学会雑 誌, 36, 61-86 (1995).

17）鎗田響子他, 投稿中

18) Lowbury E. J. L. et al., "Control of Hospital Infection, 2 nd ed.", Chapman \& Hall, London, 1981, pp.247-250.

19）神谷晃，尾家重治,“消毒薬の選び方と使用上の 留意点”, 薬業時報社, 東京, 1992, pp.117-118. 